\title{
Erratum
}

Int J Biometeorol (1987) 31:217-235

\section{Vergleich der Strahlungsverhältnisse über einem Buchenwald, zwei Kiefernwäldern und einer Grasfläche}

\author{
J. van Eimeren \\ Gartenstrasse 23, D-8050 Freising, Federal Republic of Germany
}

Page 217: The chapter: „Die Meßstandorte und die Meßanordnungen“ (6 lines) has to be read after line 3 on page 218 .

Page 222: Table 2, line „Ausstrahlung der Erdoberfläche (E)“", $\mathrm{HH}$, November: read 338,9 instead of 388,9.

Page 230: Insert ,Der Umrechnungsfaktor ist $0.22 \mathrm{~W} \mathrm{~m}^{-2} / \mu \mathrm{E} \mathrm{m}^{-2} \mathrm{~s}^{-1}$.“ after „haben" in line 7 from bottom.

Page 234: Transfer the chapter "Zusammenfassung“ to page 217 after the ,Abstract". 